\title{
Chapter 14 The Work of Peace: World War One, Justice and Translation Through Art
}

\author{
Jennifer Balint" / Neal Haslem ${ }^{* * *}$ / Kirsten Haydon ${ }^{* * *}$
}

\section{Introduction}

What work do we want law to be doing, and what work do we want to do with law and the records of war? In considering the 'peace through law' offered by the Treaty of Versailles, the peace treaty that formally ended the First World War, alongside the records of the war such as letters and artefacts and judgements, this chapter considers what it means to translate these records of war and law in order for them to be integrated and heard. Through considering a range of art practices focused on legal and other records-including Minutes of Evidence, which reactivates historical archives of a quasi-judicial body to raise awareness about issues of justice in Australia, and Flowers of War, a contemporary artwork that draws from records of the First World War to elicit public engagement-it asks us to consider ways in which legal and other records may be 'translated' and engaged with.

James Boyd White wrote that 'Law should take as its most central question what kind of a community we should be, with what values, motives and aims; it is a process by which we make ourselves by making our language.' We make our community through making law. Yet how to move from statement of intent to sustainable change? From individual or

* Associate Professor in Socio-Legal Studies, Criminology, School of Social and Political Sciences, The University of Melbourne; Chief Investigator, Minutes of Evidence Project <www.minutesofevidence.com.au>; jbalint@unimelb.edu.au.

** Senior Lecturer and Associate Dean, Communication Design, School of Design, RMIT University; Collaborator/Artist, Flowers of War $<$ http://flowersofwar.or g>; neal.haslem@rmit.edu.au.

*** Lecturer and Studio Leader, Gold \& Silversmithing, School of Art, RMIT University; Collaborator/Artist, Flowers of War $<$ http://flowersofwar.org; kirsten.haydon@rmit.edu.au>.

1 James Boyd White, Heracles' Bow: Essays on the Rhetoric and Poetics of the Law (University of Wisconsin Press 1989) 42. 
state accountability, to structural and societal change? How do we as individuals and communities take carriage of this? How do we contest the absences and exclusions of law? This chapter argues that the critical work of law that must be done is in 'translation' from its record to the individuals and society to which it is directed, and back again. That the 'work' of law - of peace through law-resides in the public as necessary partners.

The process of art as a way of production of meaning is increasingly being recognized as a congruent means to achieve this work of 'translation'. As a process based on individual experience, art has been shown to create that personal space to facilitate recognition and change. Art creates personal spaces within public frameworks. Art does not replace the accountability process of law-yet it can give it personal resonance. Agata Fijalkowski and Sigrun Valderhaug have written of this as both an affective and reflexive experience or encounter. ${ }^{2}$ Art can create its own processes of recognition and accountability when law fails. This is not art of, but art as collaboration, that uses existing legal and other records to make visible and engage the participant-verbatim and documentary theatre, public art and installations. Without societal recognition of and engagement with judgments, treaties and legislation - which comes both from personal integration and from structural change-accountability will not go beyond the courtroom or the legislature. Art can enable both a process of integration of law as well as a means of calling law to account, of naming absences in law, and of creating and enabling individual and societal processes of recognition. As a process that is both communal and individual, art works in a different register to law and the state, meaning that it can work at a level of possible transformation and change.

\section{Translating Foundational Moments}

The Versailles Treaty between the Allies and Germany was signed in June 1919. This formal legal treaty with Germany had as its preamble a desire by the Allied and Associated Powers that 'the war in which they were successively involved directly or indirectly ... should be replaced by a firm, just and durable Peace. ${ }^{3}$ Peace, however, requires work. The frameworks that

2 Agata Fijalkowski and Sigrun L Valderhaug, 'Legal Decisions, Affective Justice, and Moving On?' (2017) 7 (2) Oñati Socio-legal Series 337, 340.

3 Treaty of Peace with Germany (Treaty of Versailles) (signed 28 June 1919, entered into force 10 January 1920), Preamble. 
law establishes require activation. The spaces and stories that law does not recognize need hearing. This can be particularly important when legal records get buried and rewritten through politics, or claims to law get subverted.

That the translation of law must be personally activated, and personally heard, can be seen across much law and society work. In early legal sociological writing, Leon Petrażycki identified that for law to be effective, there must be a personal connection. With a goal of a society based on 'rational and neighbourly active love, he argued that, 'The true practice of civil law or any law is not to be found in the courts, but altogether elsewhere. Its practitioners are not judges and advocates, but each individual citizen...4

He saw law as a form of 'ethical experience', and distinguished between state official law and what he termed 'intuitive unofficial law', 'those legal experiences that contain no references to outside authorities.' The relationship between the two was critical for law to be effective. As Reza Banakar explains: 'For positive [state official] law to become an effective social tool it had to be understood as an integral part of the larger mechanisms of social organization, upon which it is dependent for its existence.6 There is a push-pull between this social or 'unofficial law' and 'official law'. Much socio-legal scholarship has built on this-law is less effective when it runs counter to dominant normative orders in a society; yet social change can be motivated by key legal judgments and legislation. As Banakar notes, 'intuitive legal experiences can challenge official law forcing the legislature to revise its rules of application. At the same time, the official law can create the basis for intuitive legal experiences.' ${ }^{7}$ Most recently in relation to Petrażycki's legacy, Roger Cotterrell has suggested:

At a time when law is often seen as a mere technical calculus, divorced from the moral experience of citizens, Petrażycki's voice from a centu-

4 Petrażycki, Wstęp do nauki polityki prawa [Introduction to the Science of Legal Policy] ([1897] Warsaw, 1968), 138-39. As quoted by Krzysztof Motyka, Law and Sociology: The Petrazyckian Perspective in Michael Freeman (ed), Law and Sociology: Current Legal Issues 2005 (OUP 2006) 119, 134.

5 See further, Adam Podgórecki, 'Unrecognized Father of Sociology of Law: Leon Petrażycki' (1980-81) 15 Law and Society Review 183; Andrzej Kojder, 'Leon Petrażycki's Socio-legal Ideas and their Contemporary Continuation' (2006) 6(3) Journal of Classical Sociology 333.

6 Reza Banakar, 'Sociological Jurisprudence', in Reza Banakar and Max Travers (eds), An Introduction to Law and Social Theory (Hart Publishing 2002) 42.

7 ibid 40. 
ry ago insists that studies of law in action can and should be guided by a vision of what an ethical life and a well-organized society might be. ${ }^{8}$

Petrażycki demonstrated the necessity of a personal connection to the law. Law must have meaning. But how to activate this? How to translate this? How to move law from words on a page to translation and integration?

The Treaty of Versailles included the Covenant of the League of Nations, underpinned as outlined in the preamble to Part I,

by the acceptance of obligations not to resort to war,

by the prescription of open, just and honourable relations between nations,

by the firm establishment of the understandings of international law as the actual rule of conduct among Governments, and

by the maintenance of justice and a scrupulous respect for all treaty obligations in the dealings of organised peoples with one another. ${ }^{9}$

As a 'foundational moment'10 expected to establish lasting peace, the Treaty of Versailles also had large ambitions for international justice in a broader sense. It was expected to mark a moment between the past and the present, to outline a just and fairer future. As a 'foundational moment', it was expected to create new normative frameworks for the states and nations of the world: that they not resort to war, that they abide by international law, that they maintain justice not only in their dealings with one another, but also with regard to the populations under their jurisdiction. But how was this translated on the ground? What was required and what impact did these ideals have?

Article 23 of the Treaty held many of these ambitions. Going beyond the League's core mandate of settling international disputes and guaranteeing international peace and security, it endowed the new organization with a much broader mission of institutionalized technical, social and economic cooperation at a universal level. According to Article 23, the League 'will endeavor to secure and maintain fair and humane conditions of labour for men, women, and children, both in their own countries and in all countries to which their commercial and industrial relations extend, 'undertake to secure just treatment of the native inhabitants of territories

8 Roger Cotterrell, 'Leon Petrażycki and Contemporary Socio-Legal Studies' (2015) 11(1) International Journal of Law in Context 1, 9.

9 Treaty of Versailles, Preamble (n 3).

10 See further Jennifer Balint, Genocide, State Crime and the Law: In the Name of the State (Glasshouse/Routledge 2012) 6, 88 . 
under their control', 'will entrust the League with the general supervision over the execution of agreements with regard to the traffic in women and children, and the traffic in opium and other dangerous drugs', 'will entrust the League with the general supervision of the trade in arms and ammunition with the countries in which the control of this traffic is necessary in the common interest', 'make provision to secure and maintain freedom of communications and of transit and equitable treatment for the commerce of all Members of the League', and 'will endeavour to take steps in matters of international concern for the prevention and control of disease'.

We can imagine how critical these statements were at the time, encapsulated in a binding legal document coming at the end of 'the war to end all wars', with its devastation of an estimated 16-18 million civilian and military deaths. The hope of the League of Nations, was that it be a means of lasting peace and justice. The knowledge of this destruction was acknowledged in this document of law: as criminologist Stanley Cohen has noted, 'Acknowledgment is what happens to knowledge when it becomes officially sanctioned and enters the public realm. ${ }^{11}$

Despite its forward-looking character, Article 23 of the Treaty of Versailles - which essentially established the League of Nations as an organization that would not only guarantee the peaceful settlement of disputes among its members, but also ensure the interests of humanity as a wholestill encapsulated some knowledge of the war. In particular, Article 23(e) in its provision of equity of commerce, noted that 'the special necessities of the regions devastated during the war of 1914-1918 shall be borne in mind.' This was meant to safeguard certain war-torn industrialized countries, notably France, against unfair competition from abroad. By contrast, the drafters of the League Covenant chose to ignore the aspirations that the war had raised in other regions around the world. Most prominently, despite hundreds of thousands of non-European troops and labourers having served on and behind their frontlines, and countries like Japan and China having joined the fight against the Central Powers, they refused to define racial equality as a key principle of the new organization. ${ }^{12}$

We must ask what conceptions of governance and race informed the new international body which was expected to facilitate peace? What lived realities and injustices inhabited it? Article 22 of the Treaty of Versailles, critically, established the 'mandate' system, whereby former colonies 'in-

11 Stanley Cohen, 'State Crimes of Previous Regimes: Knowledge, Accountability, and the Policing of the Past' (1995) 20(1) Law \& Social Inquiry 18.

12 See Castellanos-Jankiewicz (ch 5). 
habited by peoples not yet able to stand by themselves under the strenuous conditions of the modem world', could be 'entrusted to advanced nations who by reason of their resources, their experience or their geographical position can best undertake this responsibility. ${ }^{13}$ Colonialism underlay the very concept of international justice, a state-based system where a sovereignty that overrode Indigenous sovereignties was the basis of membership. ${ }^{14}$ This framework underlay what stories of harm were heard, and what were not.

\section{Ottoman Courts-Martial}

Another core absence during the Paris peace negotiations was the concept of genocide. While the Treaty of Versailles was being formulated, in another part of the continent the Ottoman State was reckoning with its past in a Courts-Martial that was not only largely ignored by the world, but obstructed. This Courts-Martial, before its demise, was to establish a critical legal record that established accountability for the genocide of the Armenian people by the Ottoman State. ${ }^{15}$ An estimated 1.5 million Armenian citizens of the Ottoman State were killed. There had been recognition of this during the war by the Allies, backed up by many eyewitness reports of consular staff and religious clergy. ${ }^{16}$ In fact, on 24 May 1915 the Allies had declared:

13 See Hébié and Baldini Miranda da Cruz (ch 4).

14 For further discussion, see Jennifer Balint, Julie Evans and Nesam McMillan, 'Rethinking Transitional Justice, Redressing Indigenous Harm: A New Conceptual Approach' (2014) 8 The International Journal of Transitional Justice 194, 203-204; see also James Anaya, Indigenous Peoples in International Law (OUP 2004); Anthony Anghie, Imperialism, Sovereignty and the Making of International Law (CUP 2005).

15 For a longer discussion of the Ottoman Courts-Martial, see Jennifer Balint, 'The Ottoman State Special Military Tribunal for the Genocide of the Armenians: Doing Government Business' in K J Heller and G Simpson (eds), The Hidden Histories of War Crimes Trials (OUP 2013) 77-100. See also, Vahakn N Dadrian and Taner Akçam, Judgment at Istanbul: The Armenian Genocide Trials (Berghahn Books 2011).

16 See, eg, Arnold Toynbee, The Treatment of the Armenians in the Ottoman Empire (Hodder and Staughton 1916); Henry Morgenthau, Ambassador Morgenthau's Story (Gomidas Institute 1918); Suzanne Elizabeth Moranian, 'Bearing Witness: The Missionary Archives as Evidence of the Armenian Genocide' in Richard G Hovannisian (ed), The Armenian Genocide. History, Politics, Ethics (St Martin's Press 1992) 103-128; Marjorie Housepian Dobkin, 'What Genocide? What Holocaust? News 
In view of these new crimes of Turkey against humanity and civilisation, the Allied governments announce publicly ... that they will hold personally responsible ... all members of the Ottoman government and those of their agents who are implicated in such massacres. ${ }^{17}$

The Peace Treaty of Sèvres between the Allies and Turkey, signed in August 1920, entailed recognition of this in its Articles 142, 144, and 230 which refer to the establishment of a Tribunal and undertook to 'repair so far as possible the wrongs inflicted on individuals in the course of the massacres perpetrated in Turkey during the war' (Article 142). ${ }^{18}$ While genocide was not mentioned, the framer of the concept Raphael Lemkin has said that accounts of the massacres had influenced his development of the term. ${ }^{19}$ Yet the court provided for in Article 230 of the Treaty of Sèvres-imitating the solution they had adopted with regard to German war criminals in Article 228 of the Treaty of Versailles, the Allies reserved 'the right to designate the tribunal which shall try the persons so accused'-never eventuated, and in fact the Peace Treaty of Sèvres was abandoned, signed but never ratified. The last paragraph of Article 230 of the Treaty of Sèvres even provided for a court established by the League of Nations to be the designated tribunal. The successor to the Treaty of Sèvres, the Treaty of Lausanne, was to omit all mention of war crimes. ${ }^{20}$

Despite the earlier pronouncements of the Allies, it fell to the Ottoman State to initiate legal proceedings. The process began in the Ottoman Parliament. The Armenian massacres had become the primary topic of conversation in the Parliament, with one parliamentarian decrying '[w]e inherit-

from Turkey, 1915-1923: A Case Study' in Richard G Hovannisian (ed), The Armenian Genocide in Perspective (Transaction Publishers 1998) 97.

17 Cited in Vahakhn Dadrian, The History of the Armenian Genocide. Ethnic Conflict from the Balkans to Anatolia to the Caucasus (3rd edn, Berghahn Books 1997), 216.

18 Treaty of Peace between the Allied and Associated Powers and Turkey (signed 10 August 1920) 28 LNTS 225.

19 The first draft, proposed by Russia, contained the phrase 'crimes against Christianity and civilisation', but it was changed to 'crime against humanity and civilisation' by France in light of the Muslim populations in the French colonies: see Ulrich Trumpener, Germany and the Ottoman Empire (Princeton University Press 1968), 210, footnote 26. The term 'crimes against humanity' was the original charge, yet due to opposition by the United States, who preferred 'crimes against the law of war', and Japan, it was changed to massacres.

20 Treaty of Peace with Turkey, with Related Documents Signed at Lausanne (signed 24 July 1923, entered into force 6 August 1924) 28 LNTS 11. 
ed a country turned into a huge slaughterhouse. ${ }^{21}$ The media also heavily reported the massacres, with one newspaper arguing for Parliament's dissolution, stating that 'It is impossible to appear before humanity and civilization hand in hand with those who had worked with the organizers of the Armenian massacres.22

It was on 2 November 1918 that a motion for a trial of the ministers of the two wartime cabinets was introduced by a Deputy in the Chamber of Deputies of the Ottoman Parliament, invoking 'the rules of law and humanity' Two inquiries were subsequently established in late November 1918 and the Courts-Martial were established by Imperial authorization on 14 December 1918. The Courts-Martial prosecutors relied on the Ottoman Penal Code for the charges. Prior to the establishment of the trials, over 200 files had been prepared on individual government, military and Party officials as alleged perpetrators. Along with the trial records, these resulted in an extensive documentary record of the genocide.

At least sixty-three trials were held within the framework of the CourtsMartial, organized as follows: Ittihadist leaders and Central Committee members; Ministers of the two wartime cabinets (these first two were merged after the sixty-three prisoners were taken by the British to Malta and Mudros in May 1919); Responsible Secretaries and Delegates (who organized and supervised deportations) and those of the 'Special Organization' (who did the killings); and officials in provinces where the massacres took place. The trials provided a clear record of the crimes perpetrated. For example, in the trials in the province of Yozgat, which held to account local officials responsible for the deportation of Armenians from that community, an affidavit from the Military Commandant of Yozgat noted that 'underlying the entire scheme of deportations lay "a policy of extermination" (imba siyaseti). ${ }^{23}$

The ascendancy of Kemalism and the establishment of the modern nation state of Turkey resulted in the demise of the Courts-Martial. On 29 April 1920, a bill was introduced in the new Kemalist National Assembly in Ankara that nullified the official decisions and decrees of the Sultan's Istanbul government. In July that year the guilty verdicts of the former Governor of Baiburt, Mehmed Nusret, and Mehmed Kemal, who had been

21 John S Kirakossian, The Armenian Genocide: The Young Turks Before the Judgment of History (Sphinx Press 1992) 162.

22 ibid 158.

23 Vahakn N Dadrian, 'The Turkish Military Tribunal's Prosecution of the Authors of the Armenian Genocide: Four Major Courts-Martial Series' (1997) 11 Holocaust and Genocide Studies 37. 
sub-district governor of Bogazliyan and subsequently interim district governor of Yozgat, and who had both been executed, were overturned. They were declared 'national martyrs'. On 31 March 1923, a general amnesty was announced for all those convicted by the Courts-Martial as well as by civilian courts, with pensions provided to families and a region, a school and street named in honour of Nusret, and a statue of Kemal erected. ${ }^{24}$

Yet we have these records. The Ottoman Courts-Martial established at the end of World War I provides a clear statement on the genocide of Armenians. With the subsequent and continuing denial of the genocide by the Turkish state, these records are critical. Aside from victim and witness testimony, the only authoritative statement of the fact of the massacres are these records from the trials at the end of World War I. These recordsthose that still exist, much was destroyed-and the fact the Courts-Martial was held-remain as evidence. In a situation of continued denial by Turkey, this is important.

Legal and other records can create new meeting points, new means of recognition, both inside and outside law. ${ }^{25}$ In bringing these outside of law, they can be 'translated' and heard. This process of translation and of engagement is a critical means of social and structural change. Despite the official condemnation and recognition of the genocide through statements in the Ottoman Parliament and the media, the wider population appeared reluctant to accept the legal process and its verdicts. Due to this public unwillingness to accept Armenian testimony during the Yozgat trial, in his closing arguments the Prosecutor-General told the court that he was intentionally excluding all evidence supplied by Armenian witnesses, and was concentrating on documentary evidence and evidence supplied by former government officials. ${ }^{26}$ In this failure of translation, the Armenian genocide-although documented and condemned in courts of law-was not effectively heard by the wider community. It remains unheard today.

24 Annette Höss, 'The Trial of Perpetrators by the Turkish Military Tribunals: The Case of Yozgat' in R G Hovannisian (ed) The Armenian Genocide: History, Politics, Ethics (St Martin's Press 1992) 219. Dadrian (n 26) 52.

25 On the concept of meeting points, see Jennifer Balint et al, Keeping Hold of Justice: Encounters Between Law and Colonialism (forthcoming, University of Michigan Press).

26 Höss (n 27) 221. 


\section{Art as a Means of Making Visible}

How do we create this sense of shared humanity? Of hearing the victims and witnesses and their stories? How do we make visible these stories? When these are in courtrooms far away, with limited public access? Or when populations fail to hear them? Organized outreach activities have been a new addition to contemporary international criminal justice. Yet while these are an important means of communicating legal outcomes and processes, 'making visible' is something different to the usual outreach activities, which appear focused on relating what courts are doing, and informing communities of this (sometimes using innovative means, such as drama and visual art), yet not creating an interactive process as such.

Here, we can use the record of law and of other documents to create this. We have many thousands of pages of records of judgments, of transcripts. These reside not only in international courts, but in tribunals and commissions of inquiry. We have many more records from war, including letters that can be brought into the public domain, and used as a basis for interaction and recognition.

Increasingly, we see this process of interaction and engagement through non-legal means. For example, the exhibition My Body: A War Zone draws on local and international judgements of sexual violence in the Yugoslav War, as documented at the International Criminal Tribunal for the former Yugoslavia and in local courts. Featuring particular women's stories and their photos, alongside judgments, it opened in Sarajevo in in 2015, and was also shown in Mostar, Banja Luka, Brčko and Zenica. The showings are in public squares, on huge billboards, that are visible and invite engagement. Olivera Simić, who interviewed those involved, notes that 'Many of the young people who joined the discussions around the exhibition stated that visual art in the form of women's portraits revealed stories that would otherwise stay buried in legal documents. ${ }^{27}$ Designed as a key visual awareness raising tool, it was established to demonstrate the need for an International Protocol on Investigation and Documentation of Sexual Violence in Conflict. It itself was part of a broader project, The Legacy of Rape, which documented the testimonies of women victim survivors of sexual violence from

27 Olivera Simić, 'My Body: A War Zone: Documenting Stories of Wartime Sexual Violence in Bosnia, Herzegovina and Nepal' (2016) 8(1,2) Journal of Arts \& Communities 11, 20. See also Zuzana Pavelková, 'My Body, a War Zone: Breaking the Silence Surrounding Sexual Violence in Conflict' (Balkan Diskurs, 13 August 2015 ) <http://balkandiskurs.com/en/2015/08/13/my-body-a-war-zone-breaking-thesilence-surrounding-sexual-violence-in-conflict/> accessed 24 July 2018. 
Democratic Republic of the Congo, Nepal, Bosnia and Herzegovina, and Colombia.

When the state refuses to establish a justice process, or to even recognize the harm perpetrated, we see that civil society can establish these records independently. Responding to the failure of any state recognition of the Kurdish 'Anfal', the campaign of extermination of Kurds in Northern Iraq in 1988 led by Saddam Hussein, which involved mass deportation and chemical weapons, artist Osman Ahmed has worked with survivors to create a visual documentation of the genocide. The drawings that he has done are a result of extensive interviews with survivors, and his own witnessing, and are a clear documentary record of the harms perpetrated. ${ }^{28}$ As Ahmed wrote in his exhibition catalogue, 'Since witnessing the genocide in 1988, every drawing has been a renewal of my intent to bear witness; every tableau is a meeting place where memories and flashbacks spring to life out of chaos. ${ }^{29}$ His drawings document the harm perpetrated, as a visual image, in the absence of any state record of harm. Done collaboratively with survivors of the genocide, they have also been a powerful means of recognition for those involved.

Archival records of historical judicial or quasi-judicial proceedings may be used in a similar way. The Minutes of Evidence project used theatre, research and education to create new and collaborative ways of understanding Australia's past and the possibilities for its future. Centred on the 'minutes of evidence' of the 1881 Parliamentary Inquiry into the Coranderrk Aboriginal reserve in the colony of Victoria, Australia, this transcript of the Inquiry, alongside letters and petitions from the time, was turned into a verbatim theatre production, Coranderrk: We Will Show the Country, performed in theatres, at universities and 'On Country' to descendants of Coranderrk. Unusually for the time, the Parliamentary Inquiry heard evidence from the Aboriginal residents of Coranderrk. This testimony, alongside that of settler supporters, and of settler officials, enables these voices to be heard, that chart out alternative possibilities for living together-the just possibilities that were sought at the time-and also the structural injustices of colonialism that endure. ${ }^{30}$

28 For images, see 'Memories of Anfal' (Culture Inside) <http://www.cultureinside.com/homeen/artists-espace/gallery.aspx/viewgallery/2291/24788/> accessed 24 July 2018.

29 Osman Ahmed, Displaced, Imperial War Museum London, 31 May-7 September 2008.

30 See 'Minutes of Evidence' <www.minutesofevidence.com.au> accessed 24 July 2018; Jennifer Balint et al, 'The "Minutes of Evidence" Project: Creating Collabo- 


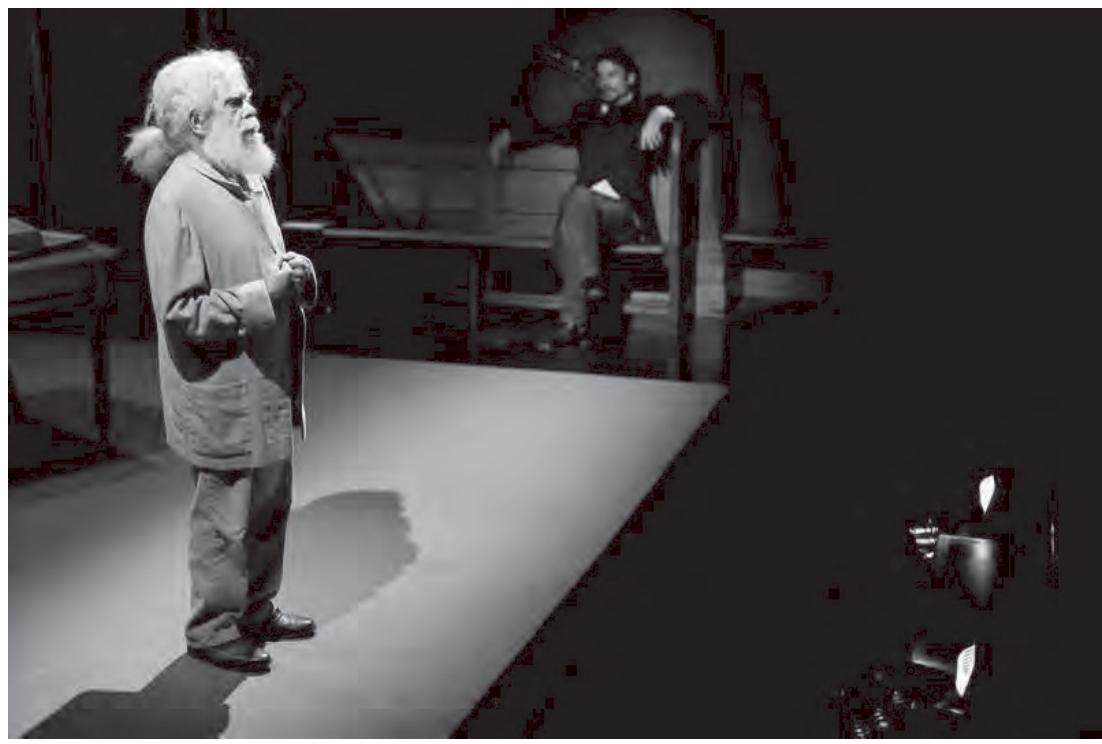

Uncle Jack Charles, playing William Barak, testifying at the Coranderrk Inquiry, with Board of Protection Secretary Captain Page, played by Tom Long:

Coranderrk: We Will Show the Country, La Mama Courthouse Theatre, 2011. Photograph: Steven Rhall.

Thirteen partner organizations, including government and community organizations, universities, education experts, performance artists and theatre practitioners, came together to create 'meeting points' through theatre, education and research. This record of law, the 1881 Parliamentary Inquiry, was used to create spaces for awareness of structural injustice, and consideration of what a just response may require. Alongside the space of theatre, the Inquiry has been used to develop new curriculum resources for government and non-government schools in Victoria in Years $9 \& 10$ History and Civics \& Citizenship to respond to the paucity of material available to teach Indigenous history and Indigenous-settler relations in Victoria. The Minutes of Evidence Coranderrk Curriculum and Teacher Resource Package includes

rative Fields of Engagement with the Past, Present and Future' in Leigh Boucher and Lynette Russell (eds), Settler Colonial Governance in Nineteenth-Century Victoria (ANU Press and Aboriginal History Inc 2015) 203; Jennifer Balint et al, 'The Minutes of Evidence Project: Doing Structural Justice' (2018) 7 State Crime Journal. 
the development of protocols for engagement with Indigenous communities around educational resources.

These 'meeting points' established in public spaces, schools, theatres, universities, and through research in Minutes of Evidence are designed to act as a catalyst for establishing awareness and possibilities in relation to the nation's past, present and future. This record of law was little known in the wider community in Victoria. Re-activating it through theatre and education, and placing it alongside other claims to justice across time and space, has enabled a broader engagement around what justice could look like. The reactivation of these legal records, through creating interactive spaces in which the record can be heard and considered, has enabled the stimulation of public engagement in issues of justice in Australia. It has meant that the claims of justice and injustice on record at the Coranderrk are heard in the present. Critically, it creates a space for consideration of what a structural justice may require.

\section{Flowers of War}

The international commemorative project Flowers of War provides an example of the way in which art can do the work to translate historical records from the past and make them vibrant catalysts of discourse in contemporary society. ${ }^{31}$ The artists, Kirsten Haydon, Elizabeth Turrell and Neal Haslem, have researched historical records and artefacts from World War I, and looked at the ways these historical objects intertwine with the symbolism and cultural connotations of flora.

The work has, as its foundation, a metal, meccano-like circular structure over two metres in diameter. This framework is given a rigidity through crossed steel members that resonate with the technology of industrialization, bridge-building and the assertion of the power of humankind to dominate and exploit their natural environment. Mounted onto this structure are individual enamelled artworks-wearable brooches-that interweave to create an enamelled steel wreath. With forms based on flowers and leaves that embody connections to the history and social commemoration of war, over 400 individual pieces are attached onto the circular framework. Each individual piece embodies, and translates, different stories and connections. Some trace individual soldier's experiences, often tragic, sometimes heroic, but personal and particular to that individual in time

31 See 'Flowers of War' < http://flowersofwar.org> accessed 24 July 2018. 
and space. One example is the piece that recollects the record of Private Arthur Elderton's cotton 'effects' bag in which the traces of his life; gold locket, wallet, badge, coins, compass, scissors and a button were sent home to his mother in New Zealand on 18 July 1916 following his death from shrapnel wounding. Another takes the form and colour of the cornflower; a flower which came to symbolize the war and the human sacrifice of the war for the French in the same way the poppy did for the Anglophone world. Another takes the form of a eucalypt leaf, yet in colouring and surface treatment connotes the rusted and burnt metal wreckage dragged up from old battlefields by farmers wishing to replant crops following the end of the war. With hundreds of these individual pieces intertwined we see the personal bound up in the geo-political-together forming a steel wreath of commemoration.

The wildflowers and leaves forming the steel wreath bring to presence individual moments of World War I. As Australian art historian Ann Elias writes, '[as] living forms, as art, and as symbols, the wildflowers that soldiers encountered in World War I Europe help us negotiate the unimaginable enormity of war and deepen the solemnity of remembrance.32 Elias goes on to discuss Elaine Scarry's writing on the strength of flowers as communicative objects. ${ }^{33}$ Scarry expands on the 'vivacity' of the arts, and with this the capacity of the floral to hold the imagination in the way that other objects brought to memory, like human faces do not. She speaks to the 'ease of imagining' a flower, and through this the capacity of flowers to provide gateways to imagining, and therefore empathising with, other concepts, ideas and histories less comfortably brought to mind.

In this way Flowers of War interweaves innumerable stories, moments and memories from World War I in a complex material artefact able to be walked around, inspected, reflected upon and experienced. As an art object, Flowers of War comes alive through individual interpretation. It is in this moment of interpretation, as translation, that the remembrance of war becomes the presence of war, its legacy to us today and its lesson for the future. As a work of art, the work that Flowers of War does is non-instrumental representation; it brings to mind but does not close the mind.

32 Ann Elias, 'Flowers, Remembrance and the Art of War' (The Conversation, 10 November 2017) <https://theconversation.com/flowers-remembrance-and-the-artof-war-86768> accessed 1 April 2018.

33 Elaine Scarry, 'Imagining Flowers: Perceptual Mimesis (Particularly Delphinium)' (1997) 57 Representations 90. 
Another key aspect-and development device-of Flowers of War is public participation. When Flowers of War has been exhibited publicly, first in New Zealand, and later in the United Kingdom, it has used public participation to grow. ${ }^{34}$ In its initial exhibition, the wreath was only half complete-it invited participation and contribution. The exhibition incorporated the opportunity for viewers to create their own flowers or leaves on paper using coloured pencils and watercolour wash. These audience-created paper flowers were, similarly to the steel artwork, combined to form another wreath - a public paper wreath. Through the daily process of paper wreath creation and recreation, the capacity for the artwork to bring historical records into current imagination is activated. This public work contributes to help the artists generate further enamelled pieces for the steel wreath. Participants are encouraged to discuss their paper flowers and provide their own stories or comments relating to the artwork. These conversations, stories and images have been used by the artists to create new enamelled brooches for the artwork. The participatory aspect of the project, along with the steel and enamel wreath itself, supports the artwork to manifest its presence in the contemporary world, as living history, lived through contemporary society and understandings.

34 It will be at the Shrine of Remembrance in Melbourne, Australia from October 2018 to November 2019. 

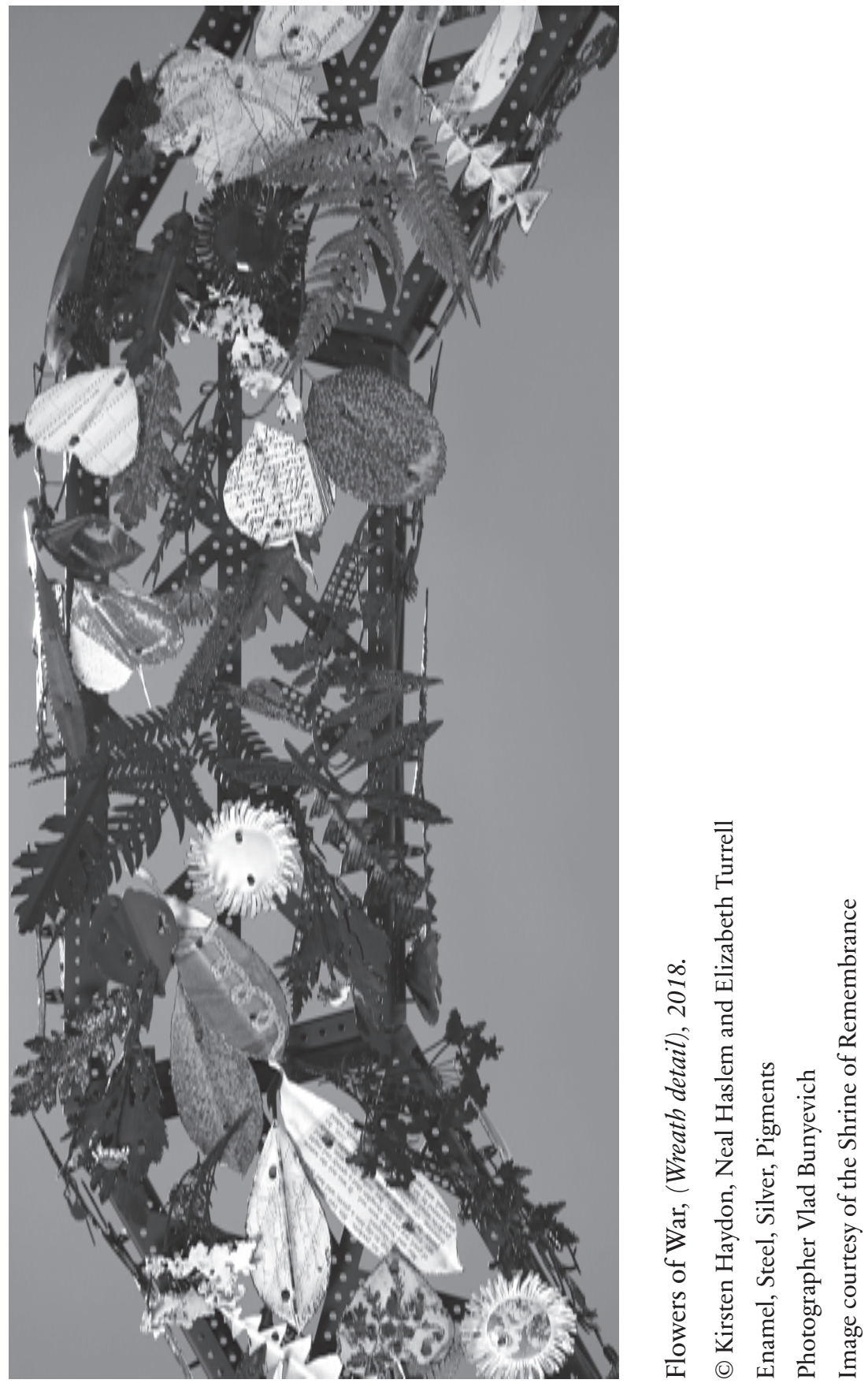


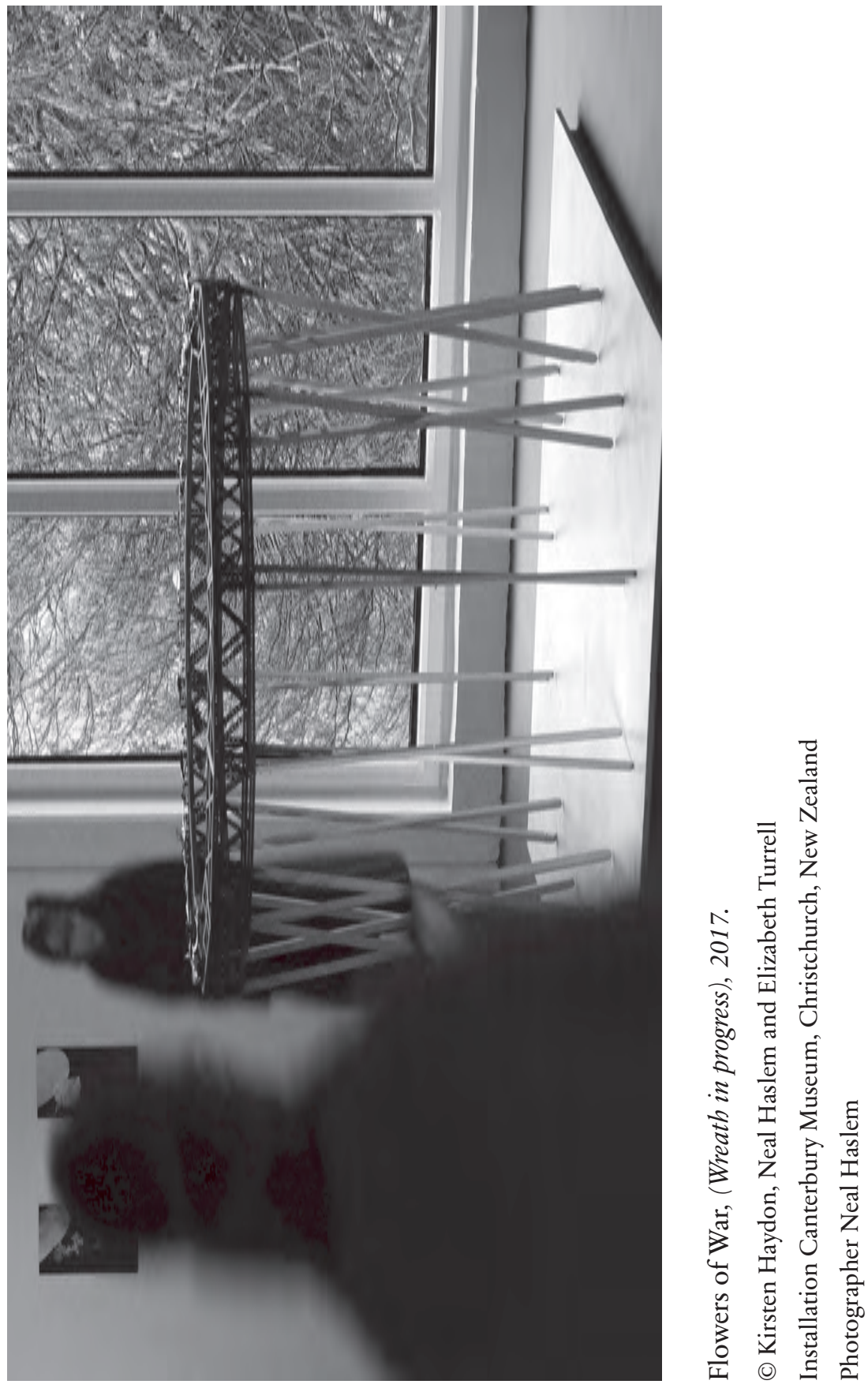




\section{Peace Through Law: Conclusion}

When we are talking of 'peace through law' the critical questions remain; how do we translate law into peace, into settlement of conflicts, into prevention? What is in fact required for peace? This chapter has argued that 'peace through law' is dependent on law's findings being translated and heard. While we may establish legal aspirations of peace inside international courts created as a consequence of the Treaty of Versailles, such as the Permanent Court of International Justice, ${ }^{35}$ the Mixed Arbitral Tribunals ${ }^{36}$ and the Arbitral Tribunal for Upper Silesia, ${ }^{37}$ we need to consider what we do with these records, these judgments? These are not foolish questions. How the work of law continues, how it becomes translated, is critical. We must hear these judgments and claims. We must use the records that we have to translate the harm and to generate our own contemporary responses, our own records. In translating our records from the past, we are able to create spaces that enable societies and individuals to take responsibility for their integration while still making visible their limitations, and to practice accountability in the present.

37 See Erpelding (ch 12). 